\title{
PENGARUH SUMBER BELAJAR SISWA TERHADAP PRESTASI BELAJAR PKN SISWA KELAS VII DI MTSN NGAWI SEMESTER GENAP TAHUN PELAJARAN 2014/2015
}

\author{
Nurhadji Nugraha* \\ Indriyana Dwi Mustikarini** \\ Ahmad Alfian Zuhri****
}

\begin{abstract}
Abstrak
$\mathrm{P}$ enelitian ini bertujuan untuk mengetahui pengaruh sumber belajar terhadap prestasi belajar PKn siswa MTS Ngawi. Penentuan sampel di dalam penelitian ini menggunakan sampel random. Sampling yaitu siswa MTS Negeri kelas VII sebanyak 40 orang. Pengumpulan data menggunakan metode observasi dan angket. Data dianalisis menggunakan metode statistik dengan rumus regresi sederhana dan korelasi produk moment. Hasil penelitian menunjukkan bahwa tingkat prestasi belajar PKn siswa di MTS Negeri Ngawi kelas VII berdasarkan uji hipotesis dengan menggunakan rumus korelasi product moment didapatkan hasil $\mathrm{r}$ hitung : 0,528 dengan taraf signifikan $\mathrm{r}$ tabel 5\%: 0,244 dan 1\%:0,317. Artinya, $r$ hitung > r tabel maka Ho ditolak dan Ha diterima. Jadi, ada pengaruh yang cukup antara sumber belajar dengan prestasi belajar PKn siswa kelas VII di MTsN Ngawi Semester Genap Tahun Pelajaran $2014 / 2015$.
\end{abstract}

Kata Kunci: Sumber Belajar, Prestasi Belajar

\footnotetext{
* Dosen Prodi PPKn IKIP PGRI Madiun

** Dosen Prodi PPKn IKIP PGRI Madiun

**** Mahasiswa Prodi PPKn IKIP PGRI Madiun
} 


\section{PENDAHULUAN}

Manusia memiliki derajat potensi, latar belakang historis, dan harapan masa depan yang berbedabeda. Karena adanya perbedaan, manusia dapat silih asah (saling mencerdaskan). Pembelajaran kooperatif secara sadar menciptakan interaksi yang silih asah sehingga sumber belajar bagi siswa bukan hanya guru dan buku ajar tetapi juga sesama siswa.

Menurut Asnawir dan Usman B (2002:115) manusia adalah makhluk hidup individual yang berbeda satu sama lain. Karena sifatnya yang individual, manusia yang satu membutuhkan manusia lainnya.Sebagai konsekuensi logis, manusia harus menjadi makhluk sosial, makhluk yang berinteraksi dengan sesamanya. Karena satu sama lain saling membutuhkan, harus ada interaksi yang silih asih (saling menyayangi atau saling mencintai). Pembelajaran kooperatif merupakan pembelajaran yang secara sadar dan sengaja menciptakan interaksi yang saling mengasihi antarsesama siswa sehingga dapat pula dipergunakan sebagai sumber belajar bagi siswa yang bersangkutan. Perkembangan informasi dan teknologi yang pesat menimbulkan pengaruh yang sangat besar terhadap perkembangan belajar siswa dirumah maupun di sekolah.

Proses belajar tidak sekadar proses mentransfer pengetahuan kognitif dari sumber belajar pada peserta didik (siswa) namun belajar merupakan suatu proses yang tampak pada optimasi keterlibatan mental emosional siswa. Pembelajaran tidak lagi mengutamakan penyerapan pencapaian informasi, tetapi lebih mengutamakan pada pengembangan kemampuan dan pengolahan informasi (Hartoyo, 2000: 24). Untuk itu, aktivitas siswa perlu ditingkatkan melalui kegiatan-kegiatan yang berkenaan dengan tataran materi yang sedang dipelajari. Kegiatankegiatan tersebut pada kenyataannya lebih memberikan pengaruh yang besar terhadap penyerapan pengetahuan serta perilaku siswa dalam kehidupan sehari-hari.

Termaktub dalam Undang-undang Nomor 20 tahun 2003 tentang Sistem Pendidikan Nasional sebagai dasar pelaksanaan pendidikan di Indonesia. Lebih lanjut dicantumkan dalam Bab II Pasal 3 bahwa "Pendidikan 
nasional

berfungsi

mengembangkan kemampuan

dan membentuk watak serta

peradaban bangsa yang bermanfaat

dalam rangka mencerdaskan

kehidupan bangsa bertujuan untuk berkembangnya potensi peserta didik agar menjadi manusia yang beriman dan bertaqwa kepada Tuhan Yang Maha Esa, berakhlak mulia, sehat, berilmu cakap, kreatif, mandiri dan menjadi warga Negara yang berdemokratis serta bertanggungjawab".

Salah satu indikator tercapainya tujuan pembelajaran dapat diketahui dari tinggi rendahnya prestasi yang diraih oleh siswa. Prestasi belajar merupakan pencerminan hasil belajar yang dicapai setelah mengikuti proses belajar mengajar. Dengan memperhatikan prestasi belajar, dapat diketahui kemampuan dan kualitas siswa. Tinggi rendahnya prestasi belajar akan memberikan sumbangan dalam mencapai kesuksesan masa depan siswa. Prestasi belajar yang baik akan mempermudah jalan untuk mencapai tujuan dalam melanjutkan studi maupun memasuki dunia kerja yang diinginkan. Oleh karena itu, setiap siswa perlu berusaha meraih prestasi yang maksimal.

\section{METODE PENELITIAN}

Penelitian ini merupakan penelitian tindakan (action research), karena penelitian dilakukan untuk memecahkan masalah pembelajaran di kelas. Penelitian ini juga termasuk penelitian deskriptif, sebab menggambarkan suatu teknik pembelajaran diterapkan dan hasil yang diinginkan dapat dicapai.

Penelitian ini bertempat di MTs Negeri Ngawi Semester Genap Tahun Pelajaran 2014/2015. Subjek penelitian adalah kelas VII MTsN Ngawi. Penelitian ini memiliki dua variabel yaitu variabel bebas dan variabel terikat. Teknik pengumpulan data yang digunakan dalam penelitian ini adalah angket. Teknik analisis data menggunakan teknik prosentasi.

$$
P=\frac{F}{N}
$$

Keterangan

$\mathrm{P}=$ Prosentasi subjek

$\mathrm{F}=$ Jumlah subjek pada suatu aspek

$\mathrm{N}=$ Jumlah seluruh subjek

Selain itu, digunakan teknik 
korelasi person product moment, untuk mengetahui pengaruh sumber belajar terhadap prestasi belajar.

$r_{x y}=\frac{N \sum X Y-\left(\sum X\right)\left(\sum Y\right)}{\left.\sqrt{\left.N \sum X^{2}-\left(\sum X\right)^{2}\right\}\left\{N \sum Y^{2}\right.}-\left(\sum Y\right)^{2}\right\}}$

Keterangan:

$r_{x y}=$ Angka korelasi $r$ product

moment

$N=$ Jumlah subjek

$X=$ Skor variabel $X$

$Y=$ Skor variabel $Y$

$\sum X=$ Jumlahs eluruh skor $X$

$\sum Y=$ Jumlah seluruh skor $Y$

$\sum X Y=$ Jumlah seluruh skor $X$ dan $Y$

Hasil perhitungan akan diinterpretasikan dengan merujuk pada nilai $r$ product tmoment pada level of significant (tingkat signifikan) 0,05. Jika hasil perhitungan lebih besar dari nilair pada tabel, korelasi dianggap signifikan atau $H_{0}$ ditolak. Artinya ada pengaruh yang signifikan antara perhatian keluarga karir terhadap prestasi belajar. Jika hasil perhitungan lebih kecil dari nilai $r$ pada tabel, korelasi dianggap tidak signifikan atau $H_{0}$ diterima.

\section{HASIL DAN PEMBAHASAN}

Berdasarkan pengumpulan data yang telah dilakukan diperoleh data penggunaan sumber belajar dan prestasi belajar sebagai berikut.

Deskripsi penggunaan sumber belajar dengan menggunakan angket yang telah diberikan kepada 40 siswa dapat diperoleh data sebagai berikut : a) jumlah skor total $=2988$, b) Rata-rata $=74,7$, c) Modus $=75$. d) Median $=75,26$, dan e) Standar deviasi sebesar 4,89 .

Dari deskripsi di atas, setelah dianalisis menunjukkan bahwa dari 40 siswa yang mendapatkan nilai di atas rata-rata(> 74,7) sebanyak 36 orang atau $90 \%$, dan hanya 4 orang atau $10 \%$ saja yang mendapat angka di bawah rata-rata. Artinya siswa sangat antusias mengikuti pembelajaran jika guru menggunakan sumber belajar yang sesuai.

Deskripsi prestasi belajar dengan menggunakan angket yang telah diberikan kepada 40 siswa dapat dideskripsikan : a) jumlah skor total $=3339$, b) Rata-rata $=83,48, c$ ) Modus $=84$, d) Median $=83,19$, dan e) Standar deviasi sebesar 3,54.

Dari deskripsi di atas, setelah dianalisis menunjukkan bahwa dari 40 siswa yang mendapatkan nilai di atas rata-rata(> 83,48) sebanyak 29 
orang atau $72,5 \%$, dan hanya 11 orang atau $27,5 \%$ yang mendapat angka di bawah rata-rata. Artinya siswa mendapatkan hasil yang baik jika pembelajaran jika guru menggunakan sumber belajar yang sesuai.

Untuk menguji hipotesis dalam penelitian ini digunakan rumus korelasi phi. Korelasi ini digunakan untuk mencari hubungan dan interval atau rasio, dan sumber data dari dua variabel atau lebih tersebut adalah sama. Untuk mengetahui ada tidaknya pengaruh sumber belajar siswa terhadap prestasi belajar PKn siswa kelas VII-C di MTsN Ngawi Semester Genap Tahun Pelajaran 2014/2015, variabel sumber belajar dan variabel prestasi belajar PKn digunakan langkah - langkah sebagai berikut:

1. Ho $: p=0$, tidak ada pengaruh sumber belajar terhadap prestasi belajar PKn siswa kelas VII MTsN Ngawi Semester Genap Tahun Pelajaran 2014/2015.

2. Ha : $p=0$, ada pengaruh sumber belajar terhadap prestasi belajar PKn siswa kelas VII MTsN Ngawi Semester Genap Tahun Pelajaran 2014/2015.
3. Kriteria uji hipotesis sebagai berikut:

Ho ditolak jika $r_{\text {hitung }}>r_{\text {tabel }}$

Ho diterima jika $r_{\text {hitung }} \leq r_{\text {tabel }}$

Selanjutnya, digunakan teknik analisis product moment untuk melihat hubungan antara variabel Sumber Belajar (variable X) dengan variabel Prestasi Belajar (variabel Y), diperoleh hasil penghitungan $r_{x y}$ sebesar 0,528.

Pengujian hipotesis dari $r_{x y}$ diketahui 0,528 dengan $\mathrm{N}=40$ maka taraf signifikan $\mathrm{r}$ tabel pada 5\% adalah 0,244 dan $1 \%$ adalah 0,317 . Jadi $r_{\text {hitung }}>r_{\text {tabel }}$ atau $\mathrm{r}$ tabel lebih kecil $r$ hitung. Artinya, Ha diterima dan Ho ditolak.

Dari $r_{\text {hitung }}$ diketahui 0,528 ,$r_{\text {tabel }} 5 \%$ adalah 0,244 dan $r_{\text {tabel }}$ $1 \%$ adalah 0,317 sehingga $r_{\text {hitung }}>r_{\text {tabel }}$ maka Ho ditolak dan Ha diterima. Dari keadaan tersebut menunjukkan variabel sumber belajar berpengaruh terhadap prestasi belajar PKn kelas VII MTsN Ngawi Semester Genap Tahun Pelajaran 2014/2015.

Hasil analisis korelasi adalah 0,528 . Hal ini menunjukkan adanya pengaruh sumber belajar terhadap prestasi belajar PKn di kelas VII 
Semester Genap Tahun Pelajaran 2014/2015.Dari hasil perhitungan regresi sederhana diperoleh $b=$ 0,134 bertanda positif, berarti :

a. Setiap kali variabel X (sumber belajar) bertambah satu, maka rata-rata variabel $\mathrm{Y}$ (prestasi belajar) bertambah 0,134 .

b. Apabila variabel $\mathrm{X}$ (sumber belajar) diketahui, variabel $\mathrm{Y}$ (prestasi belajar) dapat diperhitungkan sebagai berikut:

$\mathrm{Y}=73,47+(0,134) X$

$Y=73,47+(0,134)(75)$

$Y=73,47+10,05$

$\mathrm{Y}=83,52$

Jadi, prestasi belajar dapat penambahan dari variabel $\mathrm{X}$ (sumber belajar) bertambah satu. Rata-rata $\mathrm{Y}$ (prestasi belajar) adalah 83,52. Dari konsep regresi dapat disampaikan bahwa nilai X lebih kecil dari Y yang berarti ekstrapolasi.

\section{KESIMPULAN}

Dari sumber data prestasi belajar menunjukkan hasil yang baik. Berdasarkan uji hipotesis dengan menggunakan rumus korelasi phi hitung : 0,528 dengan taraf signifikasi $r$ tabel 5\%:0,244 dan 1\% : 0,317 , maka $r_{\text {hitung }}>r_{\text {tabel }}$ sehingga $\mathrm{Ha}$ diterima dan $\mathrm{Ho}$ di tolak. Jadi, dapat disimpulkan bahwa ada pengaruh yang cukup antara sumber belajar dengan prestasi belajar PKn siswa kelas VII di MTsN Ngawi Semester Genap Tahun Pelajaran 2014/2015. Sebagaimana dalam perhitungan regresi sederhana diperoleh data sebagai berikut:

$$
\begin{aligned}
& Y=73,47+(0,134) X \\
& Y=73,47+(0,134)(75) \\
& Y=73,47+10,05 \\
& Y=83,52
\end{aligned}
$$

Jadi, prestasi belajar dapat penambahan dari variabel $\mathrm{X}$ (sumber belajar) bertambah satu. Rata-rata Y (prestasi belajar) adalah 83,52. Dari konsep regresi dapat disampaikan bahwa nilai X lebih kecil dari Y yang berarti ekstrapolasi. 


\section{DAFTAR PUSTAKA}

Abdurahmat. 2005. Teknik Penelitian, Jakarta: Kalam Mulia.

Aqib Zainal. 2013. Model-Model, Media, dan Strategi Pembelajaran Kontekstual. Bandung: Yrama Widya.

Arifin Zainal. 1995. Evaluasi Instraksional. Bandung: Remadja Karya.

Arikunto Suharsimi. 2002. Metode Penelitian. Jakarta: Rineka Cipta.

Arikunto Suharsimi. 2010. Prosedur Penelitian Suatu Pendekatan Praktik. Jakarta: Rineka Cipta.

Asnawir dan Usman B. 2002. Pedoman Pendidikan Anak Dalam Islam. Semarang: CV Asy Syifa'.

Bahri Syaiful. 2011. Pembelajaran dan Prestasi Belajar. Jakarta: Kencana Press.

Hartoyo. 2000. Metode Pembelajaran. Jakarta: Press Media.

Malik H. Oemar. 2013. Kurikulum dan Pembelajaran. Jakarta: PT. Bumi Aksara.

Poerwodarminto WJS.1997. Kamus Besar Bahasa Indonesia.Jakarta: Balai Pustaka.

Rohani Ahmad. 1990. Pengelolaan Pengajaran. Jakarta: PT. Rineka Cipta.

Sadiman A. 1989. Prinsip-Prinsip Pengelolaan Sumber Belajar. Bandung: Remadja Karya.

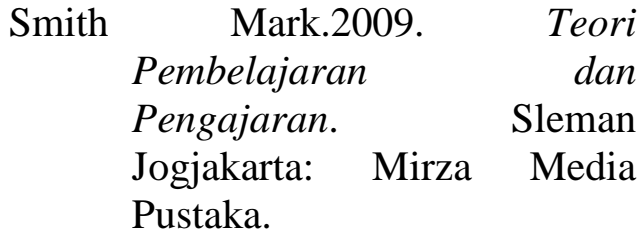

Sugiarti Titik. 1997. Penelitian Tindakan Kelas/Sekolah. Bandung: Pustaka Jaya.

SugiyoNomor 2012 Metode Penelitian Kuantitatif Kualitatif dan $R \& D$. Bandung: Alfabeta.

Tim Dosen UIN Maulana Malik Ibrahim.2012. Materi Pendidikan dan Latihan Profesi Guru. Malang: UIN Maliki Press.

Titinegoro S. 2001. Prestasi Belajar dan Faktor-Faktor yang Mempengaruhinya. Jakarta: Rineka Cipta.

UU Sisdiknas. 2003.UU RI Nomor 20 Tahun 2003.Jakarta: CV Grafika.

Winkel. 1991. Psikologi Pengajaran. Bandung: Remadja Karya 